\title{
Alternative Business Models for Energy Efficiency: Emerging Trends in the Southeast
}

An analysis of approaches to allocating the costs and benefits of ratepayer-funded energy-efficiency programs in the Southeast-a region that generally lags in energy-efficiency programs indicates that these programs would have only modest impacts on average electricity bills and rates, while significantly reducing electricity costs to participants. Utility earnings are reduced by energy-efficiency programs, but they can be restored by various business model features.

\section{Marilyn A. Brown, Benjamin Staver, Alexander M. Smith and John Sibley}

Marilyn A. Brown is an endowed Professor in the Georgia Institute of Technology's School of Public Policy. Previously, she held leadership positions at Oak Ridge National Laboratory. She has authored more than 250 publications and two books including Climate Change and Global Energy Security (MIT Press, 2011). Her research focuses on the design and impact of policies aimed at accelerating the development and deployment of sustainable energy technologies, with an emphasis on the electric utility industry, climate adaptation, and the integration of energy efficiency, demand response, and solar resources. She was co-recipient of the 2007 Nobel Peace Prize for co-authorship of the report on Mitigation of Climate Change. Dr. Brown has served on six committees of the National Academies of Sciences and currently serves on the TVA Board of Directors and the Department of Energy's Electricity Advisory Committee.

Ben Staver completed his Masters in Public Policy at Georgia Tech as part of the Climate and Energy Policy Laboratory in 2014, prior to accepting the IGERT Fellowship. Originally from St. Louis, Missouri, he studied system dynamics at Worcester Polytechnic, where he completed his undergraduate work.

Alexander Smith studies energy policy as a doctoral candidate at Georgia Institute of Technology's School of Public Policy. His work focuses upon electric power policies and policies toward science, technology, and innovation. Smith has worked with NEMSbased models to forecast impacts of growth in demand response and other energy futures and has worked with Oak Ridge National Laboratory assessing demand response potentials. He is currently working on an evaluation of a new energy-focused academic research center in the Southeast. He is co-developer of an open-license tool called 
"GT_DSM" that is useful for assessing the impacts of utility energy efficiency programs in the Southeast U.S. Mr. Smith anticipates graduating in 2016.

John Sibley, a graduate of Yale Law School, has worked on public policy in Georgia and the Southeast throughout his career, with a focus on energy issues since 2005 . He has held public positions that include counsel to committees of the state Senate, director of the Governor's Growth Strategies Commission, and board member of the Georgia Regional Transportation Authority. He has served as president of the Georgia Conservancy, an environmental advocacy organization. After retiring from the Conservancy in 2005, he joined the Southeast Energy Efficiency Alliance as program director and is currently senior policy fellow at Southface Energy Institute.

\section{Introduction}

Electric utilities in the Southeast today face an array of challenges. The economic downturn, investments in energy efficiency, and the growth of distributed generation are posing problems for traditional cost-of-service regulation by producing sluggish demand growth. At the same time, the digital economy is placing greater value on power quality, and growing cyber threats are requiring increased attention to grid security. Finally, concerns over environmental quality and global climate disruption mean that the traditional supply-side options for power generation that have dominated the past several decades of power planning may need to be transformed, and demand-side resources merit greater attention because of their increased social value (EPRI, 2014; Kind, 2013).

This confluence of factors is difficult to comport with traditional utility business models. "Demand destruction" imposes upward pressure on utility rates, which can precipitate a downward spiral of utility revenues (Kind, 2013), as consumers react to higher rates by using more energy-efficiency measures and distributed resources like solar and combined heat and power. Demand for utility services declines further, imposing even greater pressure for utilities to increase their rates to compensate for the loss in sales, further eroding demand.

The profits of utility companies are typically a function of how much energy they sell. Under traditional rate-of-return regulation, electric utility profits are based on the total amount of capital invested in selected asset categories (such as transmission and distribution systems and power plants) and the amount of electricity sold. Accordingly, a utility company's rates are traditionally set on the basis of an estimation of costs of providing service over some period of time (including an allowed rate of return) divided 
by assumed sales of electricity over that period. If actual sales are less than projected sales, the utility will earn a smaller return on investment and could fail to recover all of its fixed costs.

As a result, traditional ratemaking procedures encourage utilities to increase electricity sales - that is, to increase "throughput" - and discourage utilities from promoting energy efficiency and distributed generation because they reduce throughput (Lesh, 2009; York \& Kushler, 2011). For several years, industry groups and think tanks have been challenging these ratemaking practices. In a joint statement in 2014, the Natural Resources Defense Council (NRDC) and Edison Electric Institute (EEI) concluded: "The retail electricity distribution business should not be viewed or regulated as if it were a commodity business dependent on growth in electricity use to keep its owners financially whole.,

The range of approaches used by utility companies across the country has engendered a lively debate about the "best practice" business model. We contribute to this debate by quantitatively evaluating the strengths and weaknesses of a range of different business models. Specifically, we examine alternative ways of compensating and incentivizing utilities to operate and expand energy-efficiency programs. While we focus exclusively on energy efficiency, much of the business model architecture that is examined may also be applicable to the broader range of factors including distributed resources that are simultaneously challenging utilities.

We begin by describing a framework for the business model options building on the "three-legged stool" concept developed over the past decade (NAPEE, 2007). ${ }^{\text {ii }}$ This framework focuses on the recovery of program costs, the recovery of lost contribution to fixed costs, and the provision of utility incentives. We then examine the design of these dimensions in four Southeastern States (Arkansas, Georgia, North Carolina, and Virginia) and by one national leader, Massachusetts. After describing our research methodology, we present the results of our calibration of the impact of eight business model features: two ways of recovering direct program costs, three approaches to recovering lost contribution to fixed costs, and three methods for incentivizing utility programs.

Different business model features will be more or less attractive to different stakeholder groups depending on their particular goals. Therefore, we examine the impact 
of each of the eight business model features on four different goals: to minimize utility bills, maximize utility earnings, maximize the utility's return on equity, and minimize rate impacts. We then define and evaluate the prototypical business model in the Southeast and two alternative approaches to the three-legged stool. Our goal is to illuminate the likely impacts that different business models might have if implemented in a southeastern state.

\section{Three Ingredients of Business Model for Energy Efficiency}

Beginning in the 1970s, electric utilities and their regulators began to develop protocols for evaluating the cost-effectiveness of utility-financed energy-efficiency programs. This effort culminated in detailed program evaluation practice guides including the "California Standard Procedure Manual" and the "International Performance M\&V Manual” (IPMVP, 2001; State of California Governor's Office of Planning and Research, 2002). More recently, these tests have become imbedded in the debate over alternative business models to compensate utilities for operating energyefficiency programs.

Each of these tests uses a unique combination of costs and benefits as described by the National Action Plan for Energy Efficiency (NAPEE, 2008).

- The Ratepayer Impact Measure (RIM) test identifies the extent to which electric power rates may increase due to the deployment of a given resource option.

- The Participant Cost Test (PCT) weighs the costs and benefits to those adopting distributed resource options or participating in utility demand-side management (DSM) programs.

- The Program Administrator Cost (PAC) test weighs the costs and benefits to the utility firm seeking to deploy the given resource option or program.

- The Total Resource Cost (TRC) test estimates the net benefits of the resource option to both the utility firm and its ratepayers.

Over the past decade, the science of program evaluation has progressed rapidly, and consistent procedures have evolved to estimate a program's costs and benefits to different stakeholders. But at the same time, it has become apparent that the rates based on traditional cost-of-service regulation tend to reward throughput and not the delivery of energy services. As a result, a broader discussion has evolved, focused on "best practices" for compensating utilities for operating energy-efficiency programs. Following 
an extensive stakeholder participation process, NAPEE (2007) proposed that best practices must resemble a three-legged stool with recovery of program costs, decoupling of utility profits from electricity sales, and provision of utility performance incentives (York \& Kushler, 2011).

The recovery of program costs usually involves adjustments to rates and customer bills reflecting commission-approved budgets for energy efficiency, covering customer incentive costs, the operating costs of each program, common costs of supporting the programs, and costs of evaluation, measurement and verification $(\mathrm{EM} \& \mathrm{~V})$. These costs can either be expensed or amortized. With expensing, 100 percent of these costs are typically recovered in the year in which they are incurred. This is the general practice across the Southeast. With amortization, the commission authorizes the utility to recover program costs over some pre-defined period, including and following the year when they are incurred (perhaps over three years, or over the measure lifetime). Amortization does not appear to be used by any southeastern electric utilities.

Decoupling utility profits from electricity sales is designed to ensure that utilities are indifferent to throughput and will be kept whole when sales decline due to energy efficiency. Over the past decade, this has been accomplished principally with the development of decoupling mechanisms that use periodic rate reconciliations, typically on an annual basis, to compensate for under- or over-collection of revenues to cover fixed costs. According to the definition of decoupling used by NRDC (2012), 16 U.S. states had implemented policies to "decouple" electricity profits from sales as of 2013. This is an increase over the 9 states with decoupling in 2009. Most of the decoupling activities have occurred along the West Coast, and in the Northeast and Midwest.

There are a variety of approaches to decoupling (Regulatory Assistance Project, 2011). Most commonly, allowed revenues and rate adjustments are calculated on a revenue-per-customer basis. A per customer decoupling mechanism does a calculation ahead to determine the required rate to collect the allowed revenue per customer and then does a follow up calculation to ensure the previous year earnings fall in the correct range. This form of decoupling has been used in a number of states, but not in the Southeast, although the Arkansas Public Service Commission (PSC) has invited utilities to propose such decoupling mechanisms in upcoming rate cases. ${ }^{\text {iii }}$ 
Another approach - the "lost revenue adjustment mechanism" (LRAM) - allows the utility to recover lost contribution to fixed costs based on an estimate of energy savings and associated fixed costs. The LRAM takes the expected lost fixed cost and redistributes it over all sales by class. Our research indicates that this approach is being implemented in Arkansas, Kentucky, Louisiana, Mississippi, North Carolina, South Carolina, and Virginia.

Lost contribution to fixed costs can also be remedied by using straight fixed variable rates (SFVR). All fixed costs are recovered through a flat charge, and only variable costs are recovered through a volumetric rate. Our research indicates that this approach is used by some gas utilities in the Southeast but is not used by electric utilities.

The provision of utility performance incentives goes beyond indifference to lost revenues and creates a financial reward for energy-efficiency programs. There are three main types of incentive mechanisms. The first is based on a share of the net benefits from approved efficiency programs, as calculated using either the Total Resource Cost test or the Program Administrator Cost test (often called a "shared savings" incentive). The second allows a percentage of program costs keyed to achievement of a fixed energysaving target or a performance goal. The third provides the allowed rate-of-return, sometimes with a bonus amount, on program spending.

Hayes, Nadel, Kushler, \& York (2011) concludes that states strongly prefer incentive mechanisms that reward the cost-effective achievement of energy savings and shows that incentive mechanisms based on a share of the benefits from approved efficiency programs are the most common type of program in the U.S. Our research indicates that, in addition to the 11 states shown to practice this form of utility incentive in 2011, including Arkansas and Kentucky in the Southeast, a shared savings incentive is being implemented in Georgia, North Carolina, and South Carolina. In Georgia, North Carolina, and South Carolina, the net benefits are determined by the PAC and in Arkansas and Kentucky, by the TRC. Virginia, by contrast, allows a return on program expenses equal to the utility's return on common equity.

\section{The Prototypical Business Model in the Southeast}

States across the U.S. use different business models to compensate utilities for operating energy-efficiency programs. Because our focus is on identifying best practices 
applicable to the Southeast, our overview of current business models concentrates on four states in this region with business models that cover all three legs of the stool, using one utility from each state to provide a specific example: Arkansas (Entergy), Georgia (Georgia Power), North Carolina (Duke Energy Carolinas), and Virginia (Dominion Virginia Power). In addition, we have examined the business model used in Massachusetts, the state with the largest utility energy-efficiency program expenditures on a per capita basis in 2012, at $\$ 78$. For comparison purposes, Arkansas spent $\$ 17$, Georgia spent \$3, North Carolina spent \$6, and Virginia spent \$0.02 (Downs et al., 2013). These case studies are described in Brown, et al. (2014). Based on this research, consultations with experts in the Southeast and nationwide, and a review of the literature, we have identified the prototypical southeastern utility business model - as shown in bold italics in Figure 1.

Specifically, we have found that expensing energy-efficiency program costs is the most common approach to program cost recovery in the Southeast. The lost revenue adjustment mechanism is the most commonly used way of decoupling utility profits from electricity sales. And shared savings based on net benefits from the Program Administrator Cost test is the most frequently used way of incentivizing performance.

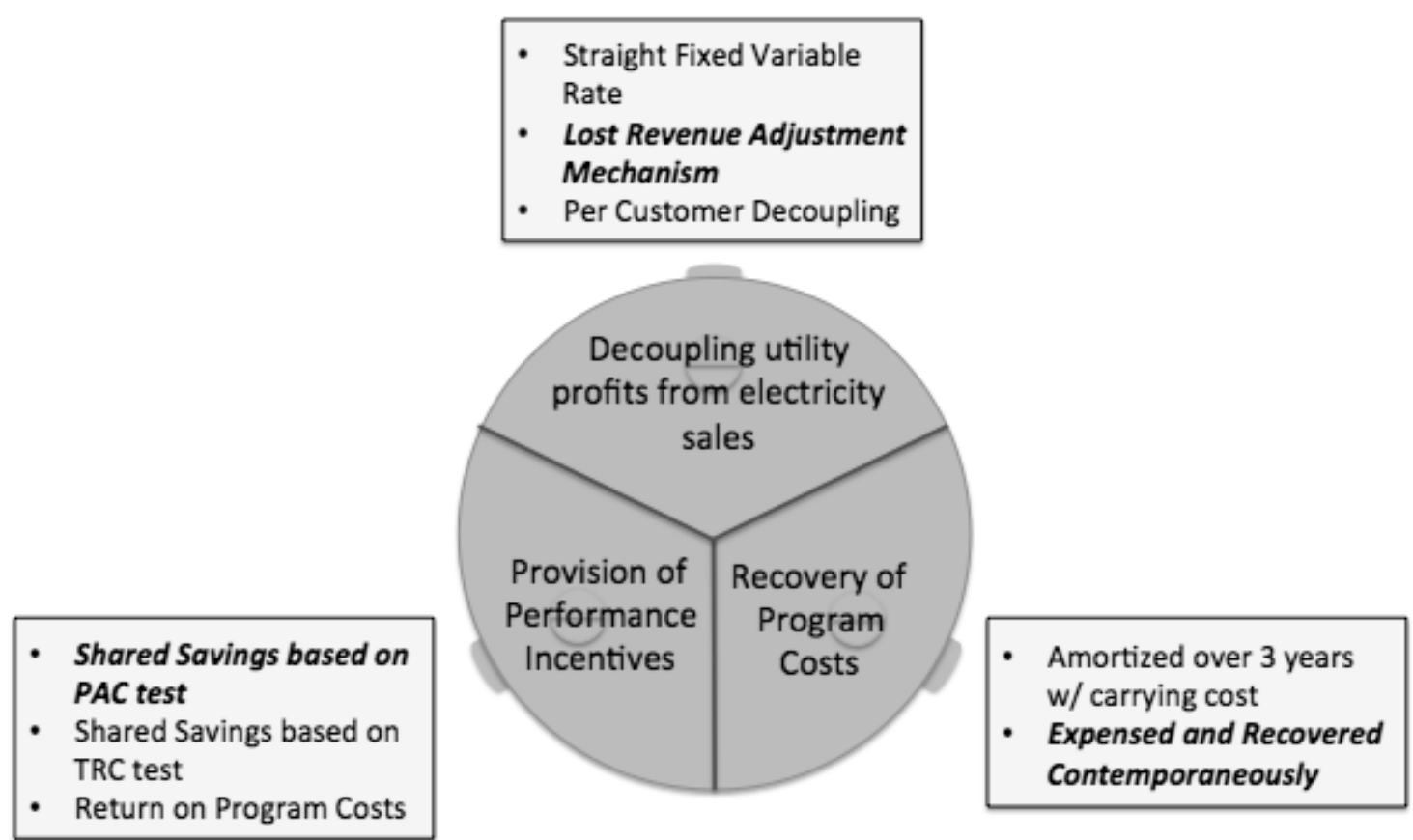

Figure 1. Eight Alternative Business Model Features and the Southeast Prototype (in bold) 


\section{Methodology}

Alternative business models for encouraging investments in utility-operated energy-efficiency programs are examined using a simulation approach. First, a "base case" is developed that represents a typical investor-owned utility in the Southeast that has not implemented energy-efficiency programs. Second, baseline metrics are developed to show the impact of energy-efficiency programs on this utility, operating in the absence of any business model features - that is, with no recovery of program costs, no decoupling of utility profits from electricity sales, and no provision for utility performance incentives. The simulated utility is assumed to operate both residential and business/commercial energy-efficiency programs. Second, each of the eight features shown in Figure 1 is added one by one to identify their impacts on cost-effectiveness metrics, as well as utility and consumer metrics. Third, we compare and contrast different approaches to the three-legged stool by combining features into the southeast prototype and two alternatives that are under discussion in the region. Further details are provided below.

\subsection{GT-DSM model}

GT-DSM is a public domain software tool developed to provide a user-friendly and accessible tool for evaluating the impacts of utility-operated energy-efficiency programs. ${ }^{\text {iv }}$ It integrates methods from existing tools as well as expanding on the level of analysis in certain areas that were identified as lacking by an advisory group. The areas of expansion include fuel cost impacts, capital investment deferrals, and potential impacts of high-consumption participants. The new tool relies strictly on publicly available information for its inputs, runs in MS Excel, and is capable of modeling key impacts to both utility firms and ratepayers. The online version of the tool is illustrated using information on energy-efficiency programs that were proposed by the Georgia Power Company in their 2013 IRP (Georgia Power Company, 2012, 2013).

The model is laid out in Sectors that cover the impacts of the energy-efficiency program to customers and to the utility.

- The Customer Sector focuses on the electricity rate and utility bill and how an energy-efficiency program affects them. To this end, the Customer Sector has two modules: the Rate Impact Module and the Bill Impact Module. In the Customer 
Sector, residential and commercial programs can be modeled, either as bundled or individual programs.

- The Utility Sector focuses on the revenues and costs to the utility and how an energy-efficiency program affects them. To this end, the Utility Sector has three modules: the Performance Incentive Module, the Deferred Capital Investment Module, and the Rate Case Module.

- The Cost-Benefit Analysis (CBA) Sector produces estimates of four of the standard cost-effectiveness tests for utility-operated energy-efficiency programs that account for different stakeholder perspectives to energy efficiency.

\subsection{Eight alternative business model features}

The eight alternative features of business models that incentivize utility-operated energy-efficiency programs are quantitatively evaluated in this article by modeling them in the GT-DSM tool. Their specifications are summarized below; their calculations are described in further detail in the GT-DSM Users Manual. ${ }^{\mathrm{V}}$

GT-DSM allows users to account for free ridership among participants in energyefficiency programs by including a net-to-gross ratio. In our analysis, we assume this ratio is 0.8 for the calculation of incentives. ${ }^{\text {vi }}$ We also assume that the shared-saving program incentives are based on 8.5 percent of the net benefits from either the PAC or TRC test, or are calculated as a return of 10 percent on program costs.

\subsection{Potential Business Models}

Three combinations of these eight business model features described above are examined. The first combines the features most commonly used in the Southeast: the "prototypical business model" defined in Figure 1. The other two combinations are based on subsets of the business model features that are under discussion in the Southeast. Alternative business model 1 combines amortized program costs, a straight fixed variable rate, and shared savings based on the TRC test. Alternative business model 2 combines expensed program costs, per customer decoupling, and shared savings based on the PAC test (Table 1).

Table 1: Definitions of Business Models Analyzed with GT-DSM

\begin{tabular}{|l|l|l|l|}
\hline & $\begin{array}{l}\text { Prototypical } \\
\text { Business Model }\end{array}$ & $\begin{array}{l}\text { Alternative } \\
\text { Business Model 1 }\end{array}$ & $\begin{array}{l}\text { Alternative } \\
\text { Business Model 2 }\end{array}$ \\
\hline $\begin{array}{l}\text { Program Cost } \\
\text { Recovery }\end{array}$ & Expensing & Amortization & Expensing \\
\hline
\end{tabular}




\begin{tabular}{|l|l|l|l|}
\hline $\begin{array}{l}\text { Performance } \\
\text { Incentive }\end{array}$ & $\begin{array}{l}\text { PAC test shared } \\
\text { savings }\end{array}$ & $\begin{array}{l}\text { TRC test shared } \\
\text { savings }\end{array}$ & $\begin{array}{l}\text { PAC test shared } \\
\text { savings }\end{array}$ \\
\hline $\begin{array}{l}\text { Decoupling } \\
\text { Mechanism }\end{array}$ & $\begin{array}{l}\text { Lost revenue } \\
\text { adjustment } \\
\text { mechanism }\end{array}$ & $\begin{array}{l}\text { Straight-fixed } \\
\text { variable rate }\end{array}$ & $\begin{array}{l}\text { Per-customer } \\
\text { decoupling }\end{array}$ \\
\hline
\end{tabular}

\subsection{Evaluation metrics}

Several perspectives are used to examine each business model. First, we use four of the five cost-effectiveness tests described in the "California Standard Procedure Manual" and discussed earlier (State of California Governor's Office of Planning and Research, 2002). Second, we evaluate the impact of alternative business models on utility economics (i.e., including utility earnings and return on equity) and on consumer economics (i.e., electricity rates and the average electricity bills of all customers, participants and non-participants).

\subsection{The stereotypical Southeastern utility and its energy-efficiency programs}

The stereotypical southeastern utility analyzed here is based on public filings describing the Georgia Power Company in 2012. Georgia Power is the largest utility in Georgia. We do not purport to replicate it in GT-DSM; instead, we use published data describing it to create a hypothetical but realistic profile of an investor-owned utility in the Southeast. The "base case" for our analysis is created by revising this profile to describe a utility that has not implemented the energy-efficiency programs proposed in 2013 and also does not have any of the business model features described in this paper.

The stereotypical utility serves 2.4 million customers, with annual sales of 81.1 TWh and a peak demand of $15.4 \mathrm{GW}$. ${ }^{\text {vii }}$ The number of customers is expected to grow by 1.0 percent per year, and sales and demand are expected to grow 1.24 percent annually. Annual earnings are $\$ 1.2$ billion based on an 11.25 percent return on equity from a rate base of $\$ 19.5$ billion. The utility's capital structure is 54 percent equity and 46 percent debt, with a cost of debt of 4.2 percent. The weighted average cost of capital is 8 percent.

Fuel and purchased power costs are collected annually through fuel charges that are adjusted periodically. These costs are assumed to increase by 6.5 percent per year. Major capital investments are programmed over the next several years to build out new baseload capacity, make environmental retrofits, and improve transmission and distribution facilities. 
Average rates are $12 \phi / \mathrm{kWh}$ for residential customers and $8 \phi / \mathrm{kWh}$ for commercial and industrial customers. Residential rates are collected through volumetric charges. The commercial and industrial rate includes a volumetric charge of $6 \varnothing / \mathrm{kWh}$, plus a demand charge, equal to $\$ 10 / \mathrm{kW}$ in the first year. The utility has a peak cost period of 2-7 pm on weekdays from June to September. This represents roughly 3.7 percent of the year. Rate cases are filed every three years.

The portfolio of energy-efficiency programs modeled here are those proposed by Georgia Power in its 2013 integrated resource planning (IRP) filing. The stereotypical utility has programmed energy-efficiency investments for 10 years. It runs two classes of energy-efficiency programs: residential and commercial. There is no industrial energyefficiency program, but we include industrial sales with the commercial sales to achieve a comprehensive analysis.

The residential program is comprised of a collection of end-use specific programs and whole home programs. The end-use specific programs include lighting, air conditioning, and other large home appliances. The whole home programs cover both existing and new homes and generally include insulation and select large appliances. These programs have annual costs of $\$ 8.3$ million for incentives and $\$ 9.8$ million for administrative costs. They are set to save $57.8 \mathrm{GWh}$ and 10.2 MW annually for each year of the measure and program lifetimes. The average measure life is assumed to be 10 years. Some 8 percent of the residential energy-efficiency program savings occur during the utility's peak period, much more than the roughly 3.7 percent of the year that occurs during the peak.

The commercial programs target both small and large commercial buildings. The small commercial program includes appliances, lighting, and insulation. The other commercial programs are from either a long list of prescriptive facility improvements or from a custom-built incentives program. These programs have annual costs of $\$ 13.7$ million for incentives and $\$ 5.5$ million for administrative costs. They are designed to save $241 \mathrm{GWh}$ and 55.3 MW annually for each year of the measure and program lifetimes. The average measure life is assumed to be 15 years. Since the programs are proposed to deploy measures for 10 years and the measures are assumed to operate for 15 years, our analysis of the impacts of these programs extends for 25 years. Some 10 percent of the 
commercial energy-efficiency program savings occur during the utility's peak period - 2 percent more than for the residential program.

The profiled programs are modest by best practice standards nationally. They are in the mid-range among portfolios of investor-owned utilities in the Southeast (Downs et al., 2013). The annual investment represents 0.5 percent of retail revenues, and the annual energy savings are a little less than 0.4 percent of sales.

\section{Results}

\subsection{The utility before implementing energy-efficiency programs, absent any business model features}

In the absence of energy-efficiency programs, the profiled utility has cumulative earnings of $\$ 47$ billion and a return on equity of 11.46 percent. The average annual bill of a residential customer is $\$ 2,533$, while the average bill of a commercial and industrial $(\mathrm{C} / \mathrm{I})$ customer is $\$ 28,107$. The average residential rate is $19 \notin / \mathrm{kWh}$, and the average $\mathrm{C} / \mathrm{I}$ rate is $12 \phi / \mathrm{kWh}$ (Table 2). These bills and rates are averaged over 25 years and are not discounted; they therefore are much higher than the average 2013 annual bills $(\$ 1,496$ and $\$ 15,348$ for residential and for C/I customers, respectively) and also higher than the 2013 rates (12 $ф / \mathrm{kWh}$ and $8 \notin / \mathrm{kWh}$ for residential and C/I sectors, respectively).

\subsection{The utility after implementing energy-efficiency programs, absent any business model features}

When implemented without applying any business model mechanisms, utility earnings over 25 years would drop by $\$ 1.2$ billion (2.6 percent) with the residential programs and by $\$ 1.8$ billion (3.8 percent) with the commercial programs. The utility's 25 -year average ROE would drop by 0.28 percentage points with the residential programs and by 0.42 percentage points with the commercial programs. Altogether, the residential programs would have less of an impact on utility and customer economics than the commercial programs.

On the customer side, average bills would drop by 1.9 percent for residential customers and by 4.8 percent for $\mathrm{C} / \mathrm{I}$ customers. Program participants would benefit from much greater bill savings ( 7.5 percent for residential participants and 20.7 percent for commercial participants). Non-participating households and C/I businesses would both benefit from a small reduction in bills due to rate reductions. Thus, without any elements 
of the business model being added, the energy-efficiency programs reduce rates by eliminating a greater proportion of more expensive on-peak than off-peak fuel expenditures. The ratio of on- to off-peak savings creates this effect, which is analogous to the demand reduction-induced price effect (DRIPE) seen in ISO-administered electricity markets and in national studies of industrial energy-efficiency programs. ${ }^{\text {viii }}$ With the DRIPE effect, both participants and non-participants can save on their electricity bills when energy-efficiency programs are introduced and utilities are not fully compensated or incentivized.

The benefit-cost tests of the energy-efficiency programs are measured as net present values (NPVs). The Ratepayer Impact Measure (RIM) test shows an NPV loss of approximately $\$ 300$ million for residential programs and $\$ 61$ million for commercial programs. These losses occur because bill savings, incentive costs, and program administrative costs would exceed the utility's avoided electric costs. This may seem counterintuitive because, while the RIM test is negative, the average rate does not increase but rather declines. Because neither lost revenue recovery nor program cost recovery has been added, the RIM test reflects the losses to the utility seen in earnings and ROE rather than increases in rates. ${ }^{\text {ix }}$ The RIM test's negative NPV is due in large part to the lost revenues/bill savings, which are favorable to customers participating in the programs.

The other three benefit-cost tests have net benefit values ranging from $\$ 146$ to \$307 million (for residential programs) and values ranging from \$788 to $\$ 2,086$ million (for commercial programs). These metrics indicate much greater benefits from the commercial programs. The largest benefit-cost test for the residential programs is from the Participant Cost Test (PCT), where the bill savings and incentive payments from the utility exceed the incremental measure cost. For the commercial programs, the largest differential is from the Program Administrator Cost (PAC) test, where the utility's avoided costs exceed the program administrative and incentive costs (Table 2).

Table 2. Impact of Energy Efficiency Programs on Utility Economics in the Absence of Any Business Model Features

a. Utility and Customer Metrics 


\begin{tabular}{|c|c|c|c|c|c|c|}
\hline & $\begin{array}{l}\text { Cumulative } \\
\text { Earnings in } \\
\text { \$Billions }\end{array}$ & $\begin{array}{c}\text { ROE } \\
(25-Y e a r \\
\text { Avg) }(\%)\end{array}$ & $\begin{array}{c}\text { Average } \\
\text { Energy Bill } \\
\text { (\$/year) }\end{array}$ & $\begin{array}{c}\text { Participant } \\
\text { Energy Bill } \\
\text { (\$/year) }\end{array}$ & $\begin{array}{c}\text { Non- } \\
\text { participant } \\
\text { Energy Bill } \\
\text { (\$/year) }\end{array}$ & $\begin{array}{c}\text { Average } \\
\text { Energy Rate } \\
(\phi / \mathrm{kWh})\end{array}$ \\
\hline $\begin{array}{l}\text { Base Case - } \\
\text { Utility Without } \\
\text { Energy- } \\
\text { Efficiency (EE) } \\
\text { Programs }\end{array}$ & 47.02 & 11.46 & $\begin{array}{l}\text { Residential: } \\
2,533 \\
\text { Commercial } \\
: 28,107\end{array}$ & NA & NA & $\begin{array}{c}\text { Residential: } \\
19.23 \\
\text { Commercial } \\
: 12.37\end{array}$ \\
\hline $\begin{array}{l}\text { Utility with } \\
\text { Residential EE } \\
\text { Programs But No } \\
\text { Business Model } \\
\text { Features }\end{array}$ & 45.84 & 11.18 & $\begin{array}{l}\text { Residential: } \\
2,484\end{array}$ & 2,343 & 2,533 & 19.22 \\
\hline $\begin{array}{l}\text { Utility with } \\
\text { Commercial EE } \\
\text { Programs But No } \\
\text { Business Model } \\
\text { Features }\end{array}$ & 45.22 & 11.04 & $\begin{array}{c}\text { Commercial } \\
: \\
26,747\end{array}$ & 22,293 & 28,070 & 12.35 \\
\hline
\end{tabular}

Features

\section{b. Benefit-Cost Tests ${ }^{b}$}

\begin{tabular}{|l|c|c|c|c|}
\hline \multicolumn{1}{|c|}{ (\$Millions) } & $\begin{array}{c}\text { Rate Impact } \\
\text { Measue Test } \\
\text { (RIM) }\end{array}$ & $\begin{array}{c}\text { Total Resource } \\
\text { Cost Test } \\
\text { (TRC) }\end{array}$ & $\begin{array}{c}\text { Program } \\
\text { Administrator Cost } \\
\text { Test (PAC) }\end{array}$ & $\begin{array}{c}\text { Participant Cost } \\
\text { Test (PCT) }\end{array}$ \\
\hline $\begin{array}{l}\text { Base Case - Utility } \\
\text { Without Energy- } \\
\text { Efficiency (EE) Programs }\end{array}$ & NA & NA & NA & NA \\
\hline $\begin{array}{l}\text { Utility with Residential } \\
\text { EE Programs But No } \\
\text { Business Model Features }\end{array}$ & -312 & 146 & 161 & 307 \\
\hline $\begin{array}{l}\text { Utility with Commercial } \\
\text { EE Programs But No } \\
\text { Business Model Features }\end{array}$ & -61 & 1,424 & 2,086 & 788 \\
\hline
\end{tabular}

${ }^{\mathrm{a}}$ Total cumulative earnings over 25 years, not discounted.

${ }^{\mathrm{b}}$ Values reported for the benefit-cost tests are the net present values of the net benefits over 25 years with a $7 \%$ discount rate for the RIM, TRC, and PAC tests and $10 \%$ for the PCT.

$\mathrm{NA}=$ not applicable

\subsection{Impact of the prototypical Southeast business model and its alternatives}

Business model features to compensate and incentivize utilities for implementing energy-efficiency programs can be combined in different ways. A preferred approach is emerging in the Southeast, but debate continues about the pros and cons of other options. Here we examine the the prototyical business model and two alternatives.

In all of the business models evaluated, combining the three legs of the stool largely restores utilty earnings and ROE to the levels of the "base case." The cumulative loss in earnings of $\$ 1.2$ billion from implementing the residential programs is reduced to \$0.1-0.2 billion. ROE rises to 11.42-11.43 percent, compared to the "base case" return of 
11.46 percent and the authorized return of 11.25 percent. The cumulative loss in earnings of $\$ 1.8$ billion from implementing the commercial programs is reduced to $\$ 0.2-0.3$ billion.

After implementation of the residential programs in combination with any of the three business models, customer metrics show savings of almost 1 percent on average bills compared to the "base case." Average rates over 25 years increase about 1.02 percent. This represents a relatively modest increase in rates over the 25 years (Figure 2). Customer metrics for the commercial programs show greater impacts on bills but similar impacts on rates as for the residential programs (Table 2). Even after implementation of the business models, average bills are reduced almost 4 percent compared to the "base case." Average rates over 25 years increase about 1.07 percent - a relatively modest increase.

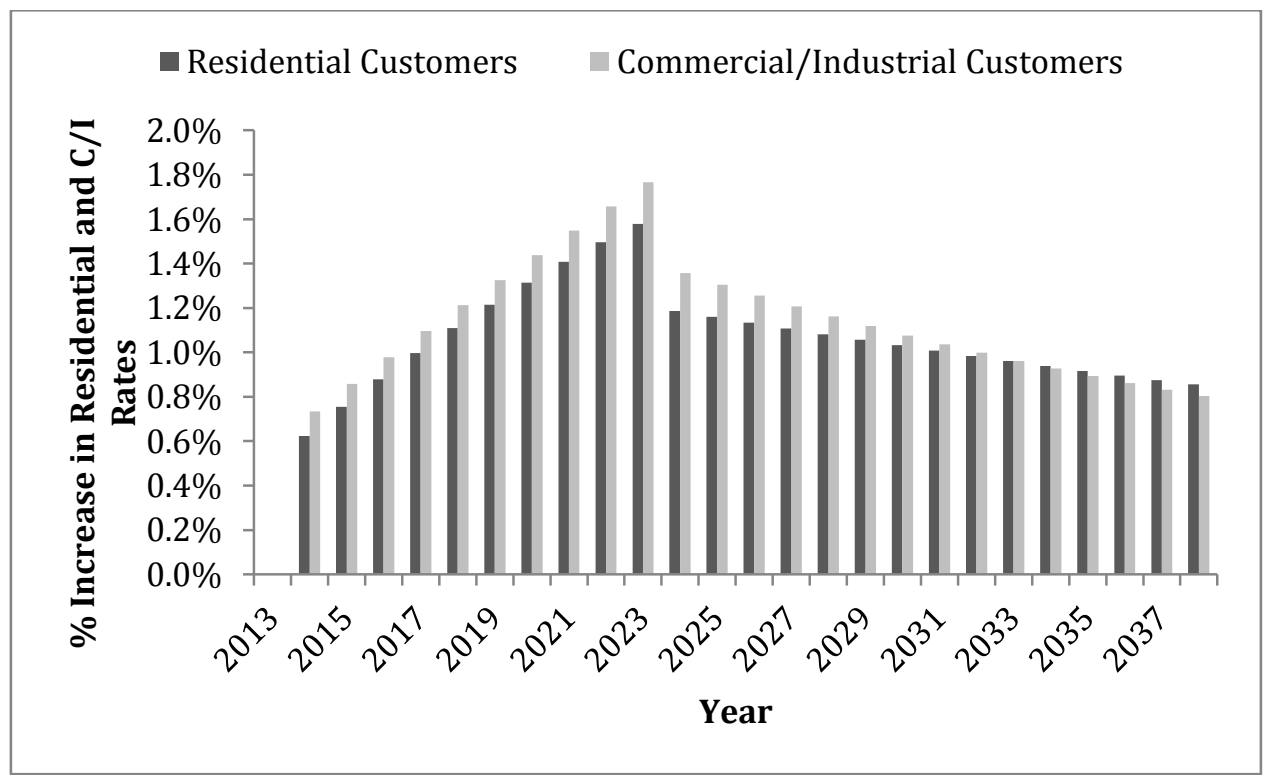

Figure 2. Impact of the Prototypical Business Model Scenario on Residential and C/I Rates (Note: Compared to "base case," the utility without an energy-efficiency program)

The three business models are distinct in how they distribute the costs and benefits of energy efficiency between utilities, participants, and non-participants. The prototypical model and the two alternative models all recover utility earnings and ROE through increases in household and C/I energy bills and rates. The prototypical business model and Alternative Model 2, which employs Per Customer Decoupling, place a smaller portion of the annual energy bill increases on participating customers than does 
Alternative Model 1, which uses the straight fixed variable approach (SFVR). ${ }^{\mathrm{x}}$ As a result, the benefit-cost tests for the prototypical business model and Alternative Model 2 are both indistinguishable from the benefit-cost tests with the residential and commercial programs in the absence of any business model features. The benefit-cost tests for Alternative Business Model 1 show distinct impacts. By reducing bill savings, the SFVR feature applied to residential programs decreases the PCT net benefit, and it decreases the net loss of the RIM test value (-\$47 billion) by reducing lost revenues (Table 3).

However, the reduction in lost revenues from SFVR for commercial programs is so large that the RIM test score for Alternative Model 1 becomes positive ( $\$ 469$ billion), making all four cost test results positive.

Table 3. Impact of the Business Models on Residential Program Economics a. Utility and Customer Metrics

\begin{tabular}{|c|c|c|c|c|c|c|c|}
\hline & & \multicolumn{2}{|c|}{ Utility } & \multicolumn{4}{|c|}{ Customers } \\
\hline & & $\begin{array}{l}\text { Earnings } \\
\text { in } \\
\text { \$Billions }^{\mathrm{a}}\end{array}$ & $\begin{array}{l}\text { ROE } \\
(25-Y \text { ear } \\
\text { Avg) }(\%)\end{array}$ & $\begin{array}{l}\text { Average } \\
\text { Energy Bill } \\
\text { (\$/year) }\end{array}$ & $\begin{array}{l}\text { Participant } \\
\text { Energy Bill } \\
\text { (\$/year) }\end{array}$ & $\begin{array}{l}\text { Non- } \\
\text { participant } \\
\text { Energy Bill } \\
\text { (\$/year) }\end{array}$ & $\begin{array}{l}\text { Average } \\
\text { Energy Rate } \\
(ф / \mathrm{kWh})\end{array}$ \\
\hline \multirow{2}{*}{$\begin{array}{l}\text { Utility with } \\
\text { EE Programs } \\
\text { But No } \\
\text { Business } \\
\text { Model } \\
\text { Features } \\
\end{array}$} & $\mathrm{R}$ & 45.84 & 11.18 & 2,484 & 2,343 & 2,533 & 19.22 \\
\hline & $\mathrm{C}$ & 45.22 & 11.04 & 26,747 & 22,293 & 28,070 & 12.35 \\
\hline \multirow{2}{*}{$\begin{array}{l}\text { Prototypical } \\
\text { Business } \\
\text { Model }\end{array}$} & $\mathrm{R}$ & 46.88 & 11.43 & 2,511 & 2,367 & 2,560 & 19.42 \\
\hline & $\mathrm{C}$ & 46.79 & 11.41 & 27,015 & 22,516 & 28,351 & 12.50 \\
\hline \multirow{2}{*}{$\begin{array}{l}\text { Alternative } \\
\text { Business } \\
\text { Model } 1\end{array}$} & $\mathrm{R}$ & 46.88 & 11.43 & 2,511 & 2,439 & 2,536 & $19.42^{\mathrm{b}}$ \\
\hline & $\mathrm{C}$ & 46.70 & 11.39 & 27,004 & 23,373 & 28,096 & $12.50^{\mathrm{b}}$ \\
\hline \multirow{2}{*}{$\begin{array}{l}\text { Alternative } \\
\text { Business } \\
\text { Model } 2\end{array}$} & $\mathrm{R}$ & 46.85 & 11.42 & 2,510 & 2,367 & 2,559 & 19.42 \\
\hline & $\mathrm{C}$ & 46.75 & 11.41 & 27,014 & 22,516 & 28,351 & 12.50 \\
\hline
\end{tabular}

Table 3. Impact of the Business Models on Residential Program Economics b. Benefit-Cost Tests ${ }^{\mathrm{c}}$

\begin{tabular}{|c|c|c|c|c|}
\hline (\$Millions) & $\begin{array}{c}\text { Rate Impact } \\
\text { Measue Test } \\
\text { (RIM) }\end{array}$ & $\begin{array}{c}\text { Total Resource } \\
\text { Cost Test } \\
\text { (TRC) }\end{array}$ & $\begin{array}{c}\text { Program } \\
\text { Administrator Cost } \\
\text { Test (PAC) }\end{array}$ & $\begin{array}{c}\text { Participant Cost } \\
\text { Test (PCT) }\end{array}$ \\
\hline
\end{tabular}




\begin{tabular}{|l|c|c|c|c|c|}
\hline $\begin{array}{l}\text { Utility with an Energy } \\
\text { Efficiency Program } \\
\begin{array}{l}\text { But No Business } \\
\text { Model Features }\end{array}\end{array}$ & $\mathrm{R}$ & -312 & 146 & 161 & 307 \\
\cline { 2 - 6 } & $\mathrm{C}$ & -61 & 1,424 & 2,086 & 788 \\
\hline $\begin{array}{l}\text { Prototypical Business } \\
\text { Model }\end{array}$ & $\mathrm{R}$ & -312 & 146 & 161 & 307 \\
\cline { 2 - 6 } & $\mathrm{C}$ & -61 & 1,424 & 2,086 & 788 \\
\hline $\begin{array}{l}\text { Alternative Business } \\
\text { Model 1 }\end{array}$ & $\mathrm{R}$ & -47 & 146 & 161 & 125 \\
\hline & $\mathrm{C}$ & 469 & 1,424 & 2,086 & 355 \\
\hline $\begin{array}{l}\text { Alternative Business } \\
\text { Model 2 }\end{array}$ & $\mathrm{R}$ & -312 & 146 & 161 & 307 \\
\cline { 2 - 6 } & $\mathrm{C}$ & -61 & 1,424 & 2,086 & 788 \\
\hline
\end{tabular}

$\mathrm{R}=$ residential program; $\mathrm{C}=$ commercial program.

${ }^{a}$ Total cumulative earnings over 25 years, not discounted.

${ }^{\mathrm{b}}$ Only a portion of this rate comes from volumetric charges, making the actual rate paid $9.55 \phi / \mathrm{kWh}$.

${ }^{\mathrm{c}}$ Values reported for the benefit-cost tests are the net present values of the net benefits over 25 years with a $7 \%$ discount rate for the RIM, TRC, and PAC tests and $10 \%$ for the PCT.

To further illustrate the differences in energy cost distribution between the three business models, Figure 3 shows the increase in energy bills by customer participation status resulting from full implementation of each business model compared to a utiity operating the energy-efficiency program with no business model features. Again, it is clear that Alternative 1 places a much larger share of the cost of residential energyefficiency programs on participating households than does either the prototypical business model or Alternative 2. The impact on the participants is large because there are so many fewer participants than customers. If more of the customers were able to participate in the programs then the participant energy cost would be closer to the average cost in Alternative 1.

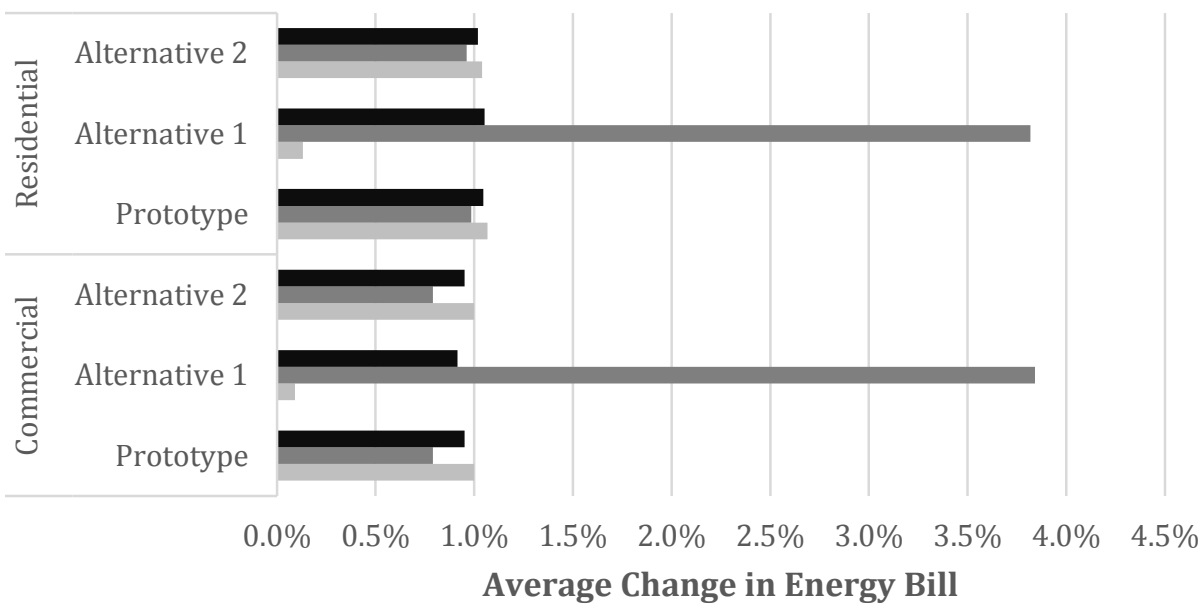

-Avg Energy Cost $\square$ Participant Energy Cost $\square$ Non-Participant Energy Cost 
Figure 3. Impact of Business Models on Utility Bills

(Note: Compared to a utility with an energy-efficiency program but no business model features)

Since debates over business models could be improved by focusing attention on the most impactful features of the business models, we examine the relative impacts on utility earnings by business model and feature for residential and commercial programs (Figure 4).We illustrate the impacts of each business model on utility earnings by comparing them to an energy-efficiency program with no business model features.

For reference, we include both the level of earnings authorized by the utility's ROE and the level of earnings achieved in the base case without any energy-efficiency program. The authorized earnings is calculated based on the 11.15 percent return on the rate base calculated in each year while the base case is drawn from the base case scenario in the tool.

Figure 4 shows clearly that the decoupling feature has the greatest impact on utility earnings, regardless of whether LRAM, SFVR, or Per Customer Decoupling is used. For residential programs, program costs represent about 15 percent of the impact of any of the business model alternatives, and performance incentives amount to less than 1 percent of total impact. Compared with the residential programs, recovery of commercial programs costs has a smaller impact on earnings, while the impact of commercial incentives is greater, but once again, the decoupling feature is dominant.

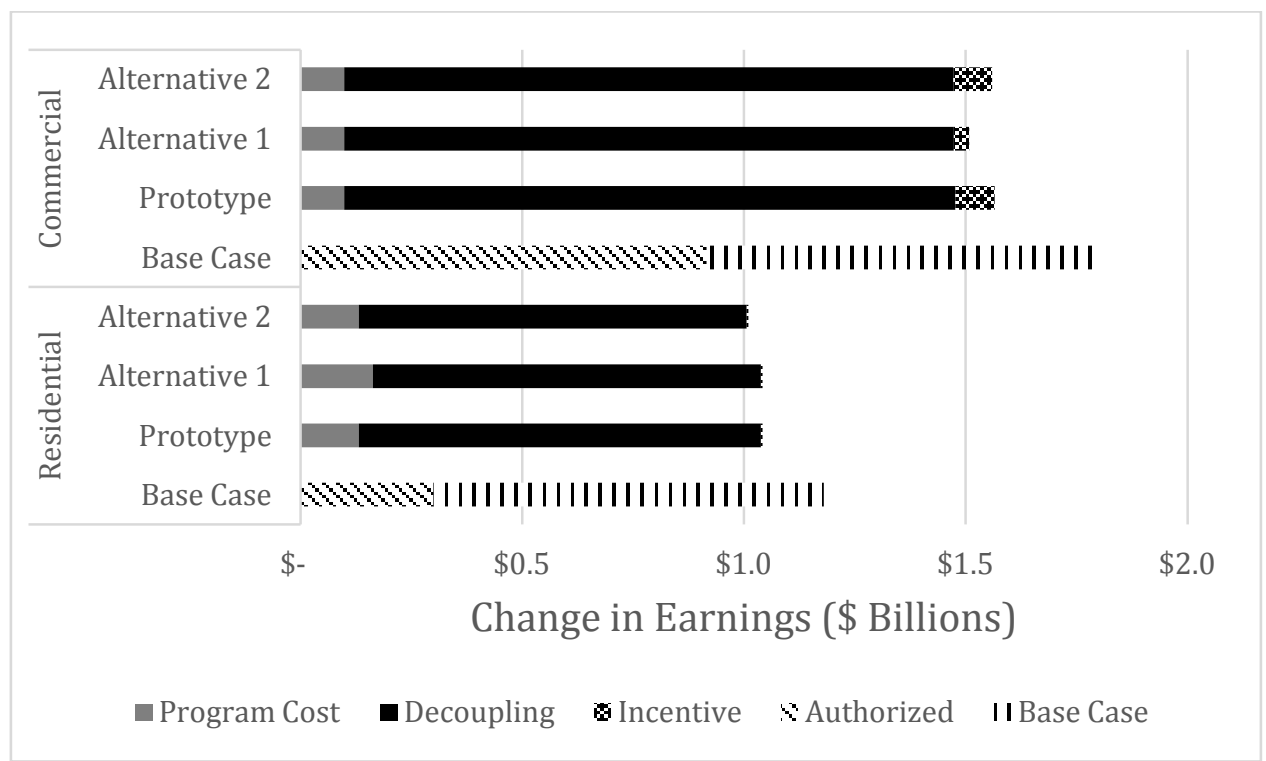

Figure 4. Impact of Business Models On Utility Earnings

(Note: Compared to a utility with an energy-efficiency program but no business model features; 
"base case" is the utility without an energy-efficiency program)

\section{Conclusions}

Our study contributes to the lively national debate about the pros and cons of rateof-return regulation that dominates the electricity industry in the Southeast. How does this traditional regulatory approach compare to the alternative business models that compensate or incentivize utilities for investing in distributed energy resources such as energy efficiency, solar energy, demand-response resources, and energy storage?

We focus on creating a fact-based and replicable set of answers to this question. Following a review of the literature, case studies, and expert consultations, we identify eight business model features to examine, including: two ways that utilities can recover program costs, three ways of recovering lost contributions to fixed costs, and three ways of providing a performance incentive to the utility. In addition, we define a prototypical southeastern business model with the most common of these features: expensing program costs, using the lost revenue adjustment mechanism (LRAM), and rewarding performance with shared savings based on net benefits from the Program Administrator Cost (PAC) test.

We analyze the impacts of these features on utility and customer economics using a stereotypical southeastern investor-owned utility that operates a mid-range energyefficiency portfolio of programs. When these programs are implemented in the absence of any business model features, the portfolio has positive scores on the TRC, PAC, and PCT tests, but a negative score on the RIM test. The RIM test indicates a benefit to participating customers, however, as well as an opportunity to share that benefit with the utility through an energy-efficiency business model. Implementation of the portfolio slightly reduces average rates over the 25 years. This downward pressure on rates is attributed to a "DRIPE" effect caused by reducing fuel expenditures during relatively expensive peak periods.

Decoupling utility profits from energy sales can have significant impact on utility and customer economics, much more than the other two legs of the business model. While the LRAM, based on a rider with annual true-up, is emerging as the norm in the Southeast, the debate on best practice is far from over. After using LRAM for three years, 
the Arkansas PSC has invited utilities to propose more fully decoupled mechanisms. The Virginia State Corporation Commissions has raised questions about the proof of lost revenues and has yet to approve a request for recovery in a rider proceeding. In North Carolina, recovery is limited to three years. Where this approach is adopted, rate increases from the LRAM would be less than from the approach modeled in this article. In Georgia, lost revenues needed to cover fixed costs are still recovered in rate cases.

The prototypical southeastern business model significantly reduces the loss in utility earnings that would otherwise accompany the implementation of energy-efficiency programs. It also produces a large increase in return on equity. While the utility's ROE still falls slightly short of the 11.46 percent rate it would enjoy without implementing the energy-efficiency programs, it exceeds the authorized rate of 11.25 percent. With the prototypical business model, average bills overall, as well as participant bills, are reduced, but the bills of non-participants would rise slightly. Average rates would increase 1 percent over 25 years.

In addition to showing that the implementation of energy-efficiency programs in conjunction with business model features would likely have modest impacts on average overall bills and rates, we have shown that the choice of business model can have significant repercussions for the utiity's earnings and profits. All approaches provide participants with lower bills but non-participant bill changes depend on the approach chosen. Business models can distribute costs across participants and non-participants equally or can allocate them primarily to participants, as is the case with the SFVR feature. The wide range of possible treatments of costs and benefits underscores the importance of selecting the business model with the best overall impacts given the goals of policymakers. This choice will become increasingly important if energy-efficiency programs grow in scope and scale as anticipated by many.

\section{References}

Baer, Paul, Marilyn A. Brown, and Gyungwon Kim. 2015. "The Job Generation Impacts of Expanding Industrial Cogeneration," Ecological Economics, 110 (2015) 141153.

Brown, Marilyn A., Benjamin Staver, Alexander M. Smith, and John Sibley. 2014. 
"Business Models for Utilities of the Future: Emerging Trends in the Southeast," School of Public Policy, Georgia Institute of Technology, Working Paper \#84.

Downs, A., Chittum, A., Hayes, S., Neubauer, M., Nowak, S., Vaidyanathan, S., Farley, K., et al. (2013). The 2013 State Energy Efficiency Scorecard. Washington, DC: American Council for an Energy Efficient Economy. Washington, DC: American Council for an Energy Efficient Economy. Retrieved from http://www.aceee.org/research-report/e13k

Electric Power Research Institute (EPRI). (2014). The Integrated Grid: Realizing the Full Value of Central and Distributed Energy Resources.

Georgia Power Company. (2012). Capacity and energy payments to cogenerators under PURPA. Retrieved from http://www.psc.state.ga.us/factsv2/Docket.aspx?docketNumber=4822

Georgia Power Company. (2013). Georgia Power Company 2013 DSM/EE Program Certification. Retrieved from http://www.psc.state.ga.us/factsv2/Docket.aspx?docketNumber=36499

Hayes, S., Nadel, S., Kushler, M., \& York, D. (2011). Carrots for Utilities: Providing Financial Returns for Utility Investments in Energy Efficiency. Washington, DC: American Council for an Energy-Efficient Economy.

IPMVP. (2001). International Performance Measurement and Verification Protocol: Concepts and Options for Determining Energy and Water Savings, Volume I. National Renewable Energy Lab., Golden, CO.

Kind, P. (2013). Disruptive Challenges: Financial Implications and Strategic Responses to a Changing Retail Electric Business. Edison Electric Institute.

Lesh, P. G. (2009). Rate Impacts and Key Design Elements of Gas and Electric Utility Decoupling : A Comprehensive Review. The Electricity Journal, 22(8), 65-71.

National Action Plan for Energy Efficiency (NAPEE). (2007). Aligning Utility Incentives with Investment in Energy Efficiency. U.S. EPA. Retrieved from www.epa.gov/eeactionplan

National Action Plan for Energy Efficiency (NAPEE). (2008). Understanding CostEffectiveness of Energy Efficiency Programs: Best Practices, Technical Methods, and Emerging Issues for Policy-Makers. Energy and Environmental Economics, Inc. and Regulatory Assistance Project. Retrieved from www.epa.gov/eeactionplan

Regulatory Assistance Project. (2011). Revenue Regulation and Decoupling: A Guide to Theory and Application. Retrieved from www.raponline.org/document/download/id/902 


\section{State of California Governor's Office of Planning and Research. (2002). California Standard Practice Manual : Economic Analysis of Demand-Side.}

\section{York, D., \& Kushler, M. (2011). The Old Model Isn't Working: Creating the Energy Utility for the 21st Century. Washington, DC: American Council for an Energy- Efficient Economy.}

\footnotetext{
${ }^{\mathrm{i}}$ The Energy Daily, Feb. 13, 42(30): pp. 1-3.

ii www.nrdc.org/media/2008/081118.asp.

iii ARPSC Docket No. 08-137-U; Order No. 19; dated Jan. 2, 2013.

${ }^{\text {iv }}$ http://cepl.gatech.edu/drupal/node/69

${ }^{\mathrm{v}}$ http://cepl.gatech.edu/drupal/node/69

vii This peak demand estimate is calculated in GT-DSM.

${ }^{\text {viii }}$ For more detail on the DRIPE effect, see Baer, Brown, and Kim (2014) and Synapse Energy Economics, Inc.:

http://www.synapse-energy.com/news/avoided-energy-supply-costs-new-england-2013-report
}

${ }^{\text {ix }}$ The RIM test result reflects the costs of energy-efficiency programs that must fall on either the utility, in the form of lost earnings and ROE; or the ratepayers, in the form of increased rates to cover the utility's losses.

${ }^{x}$ As a caveat, the results of the analysis might suggest that the LRAM and Per Customer Decoupling are equivalent; however, this will not always be the case. These two forms of decoupling have nearly identical impacts in our analysis because the underlying economic trends and the performance of the energyefficiency programs do not deviate from expectations. The LRAM will recover lost revenues to account for losses due to a program. A Per Customer Decoupling mechanism will adjust for additional deviations from the norm. This would include over- and under-collection of revenue based on weather or other unforeseen events impacting energy usage, as well as correcting the authorized amount to be collected based on unforeseen changes in the customer base. It is generally expected that the design of Per Customer Decoupling would provide a more robust preservation of utility earnings than LRAM. Our analysis is not designed to either support or refute this expectation. 